University of Nebraska - Lincoln

DigitalCommons@University of Nebraska - Lincoln

\title{
Nitrogen Mineralization Responses to Cropping, Tillage, and Nitrogen Rate in the Northern Great Plains
}

\author{
Brian J. Wienhold \\ University of Nebraska-Lincoln, Brian.Wienhold@ars.usda.gov \\ Ardell Halvorson \\ USDA, Ardell.Halvorson@ars.usda.gov
}

Follow this and additional works at: https://digitalcommons.unl.edu/usdaarsfacpub

Wienhold, Brian J. and Halvorson, Ardell, "Nitrogen Mineralization Responses to Cropping, Tillage, and Nitrogen Rate in the Northern Great Plains" (1999). Publications from USDA-ARS / UNL Faculty. 1216. https://digitalcommons.unl.edu/usdaarsfacpub/1216

This Article is brought to you for free and open access by the U.S. Department of Agriculture: Agricultural Research Service, Lincoln, Nebraska at DigitalCommons@University of Nebraska - Lincoln. It has been accepted for inclusion in Publications from USDA-ARS / UNL Faculty by an authorized administrator of DigitalCommons@University of Nebraska - Lincoln. 


\title{
Nitrogen Mineralization Responses to Cropping, Tillage, and Nitrogen Rate in the Northern Great Plains
}

\author{
Brian J. Wienhold* and Ardell D. Halvorson
}

\begin{abstract}
Nitrogen-mineralization rates are needed to accurately determine $\mathbf{N}$ fertilization requirements to meet plant needs while minimizing environmental contamination. A spring wheat (Triticum aestivum L.)-fallow (SW-F) system was compared with a Spring wheat-winter wheat-sunflower (Helianthus annuus L.) (SW-WW-SF) system on a Temvik-Wilton silt loam (fine-silty, mixed Typic and Pachic Haploborolls) at three $N$ rates $\left(0,22\right.$, and $45 \mathrm{~kg} \mathrm{ha}^{-1}$ for $S W-F$ and 34,67 , and $101 \mathrm{~kg} \mathrm{ha}^{-1}$ for SW-WW-SF) under conventional, minimum, and no-tillage. After 10 yr, soil samples were incubated to determine $\mathbf{N}$ mineralization rates. Cropping intensity, $\mathrm{N}$ rate, and tillage intensity interacted to affect $\mathrm{N}$-mineralization rates. Within the $\mathrm{SW}-\mathrm{F}$ system $\mathrm{N}$-mineralization rates in 0 - to $0.05-\mathrm{m}$ depth were $8.2 \pm 0.8 \mathrm{~kg} \mathrm{ha}^{-1}$ $w^{-1}$ in the fallow phase vs. $5.0 \pm 0.7 \mathrm{~kg} \mathrm{ha}^{-1} \mathrm{wk}^{-1}$ in the crop phase under conventional tillage and were $6.2 \pm 0.3 \mathrm{~kg} \mathrm{ha}^{-1} \mathrm{wk}^{-1}$ under minimum and no-tillage in both phases. The $\mathrm{N}$-mineralization rates were $2.3 \pm 0.4 \mathrm{~kg} \mathrm{ha}^{-1}$ wk $^{-1}$ in $0.05-$ to $0.15-\mathrm{m}$ depth soils of the $\mathrm{SW}-\mathrm{F}$ system. In spring wheat, $\mathrm{N}$-mineralization rates in 0 - to 0.05-m depth soil were $9.9 \pm 0.8 \mathrm{~kg} \mathrm{ha}^{-1} \mathrm{wk}^{-1}$ in the SW-WW-SF system vs. $5.6 \pm 0.4 \mathrm{~kg} \mathrm{ha}^{-1} \mathrm{wk}^{-1}$ in the SW-F system and in the 0.05- to 0.15-m depth were $3.6 \pm 0.1 \mathrm{~kg} \mathrm{ha}^{-1} \mathrm{wk}^{-1}$ in the SW-WW-SF system vs. $2.4 \pm 0.2 \mathrm{~kg} \mathrm{ha}^{-1} \mathrm{wk}^{-1}$ in the SW-F system Within the SW-WW-SF system, N-mineralization rates in the $0-$ to $0.05-\mathrm{m}$ soil layer were $6.8 \pm 0.5 \mathrm{~kg} \mathrm{ha}^{-1} \mathrm{wk}^{-1}$ under winter wheat vs. $9.9 \pm 0.8$ $\mathrm{kg} \mathrm{ha}^{-1} \mathrm{wk}^{-1}$ under spring wheat and $9.2 \pm 0.6 \mathrm{~kg} \mathrm{ha}^{-1} \mathrm{wk}^{-1}$ under sunflower. In the $0.05-$ to 0.15 -m soil layer, $N$-mineralization rates were $3.3 \pm 1.0 \mathrm{~kg} \mathrm{ha}^{-1} \mathrm{wk}^{-1}$. More intensive cropping and conservation tillage increased $\mathbf{N}$-mineralization rates in this soil and may ameliorate the decline in $\mathbf{N}$ fertility associated with crop-fallow systems.
\end{abstract}

$\mathrm{C}$ ROP-FALLOW has been the traditional crop production system for much of the semiarid Great Plains. More intensive cropping combined with conservation tillage has been shown to be an economical alternative (Norwood and Dhuyvetter, 1993; Dhuyvetter et al., 1996). Dhuyvetter et al. (1996) reported that economic risk decreased and net returns increased when more intensive cropping systems were used even though production costs increased. In addition, cropping rotations provide producers with management options that can be used to break weed, insect, and disease cycles (Holtzer et al., 1996); make more efficient use of available soil water (Norwood, 1994); control saline seep development (Black et al., 1981); and add stability and diversity to the farm operation. In spite of the many potential benefits associated with annual cropping, crop-fallow is still used in the Northern Great Plains. Implementing a more intensive cropping system requires adjusting

Brian J. Wienhold, USDA-ARS, Soil and Water Conservation Research Unit, Lincoln, NE 68583-0934. Ardell D. Halvorson, USDAARS, Soil-Plant-Nutrient Research Lab., Ft. Collins, CO 80522. USDA-ARS, Northern Plains Area, is an equal opportunity employer/ affirmative action employer and all agency services are available without discrimination. Received 25 Aug. 1997. *Corresponding author (bwienhold1@unl.edu)

Published in Soil Sci. Soc. Am. J. 63:192-196 (1999). management practices, such as fertilizer and pesticide inputs, to meet crop needs and control pests under the new set of conditions. Uncertainty about how conservation tillage and more intensive cropping affect soil fertility and pest populations may play a role in the reluctance of some producers to abandon crop-fallow systems.

In the semiarid Northern Great Plains, water is the factor most limiting crop production. Conservation tillage increases moisture availability, allowing the crop to more efficiently use soil nutrients (Fox and Bandel, 1986). The nutrient that most commonly limits crop growth and is applied by producers in the largest amount is N. Fertilizer rates are usually based on a yield goal, with credits given for residual soil inorganic $\mathrm{N}$, previous crop $\mathrm{N}$ inputs, and a sampling date adjustment (North Dakota State University Extension Service, 1997). Residual inorganic $\mathrm{N}$ can be estimated through sampling and laboratory analysis. A yield goal can be based on historical performance of the field or crop performance on similar soils in the area. Sampling date adjustments attempt to account for $\mathrm{N}$ mineralized from the time of sampling to the time of fertilizer application. Previous crop $\mathrm{N}$ inputs are assessed to account for $\mathrm{N}$ made available to the crop as previous crop residue decomposes and is mineralized. These last two variables are the most difficult to quantify and incorporate into the fertilizer rate calculation.

Understanding the effect of management practices on $\mathrm{N}$-mineralization rates should improve fertilizer management. Knowledge of the soil's ability to supply the crop with $\mathrm{N}$ is needed to ensure that $\mathrm{N}$ applied as fertilizer is optimized so that crop needs are met and the potential for surface and groundwater contamination is minimized. Cropping intensity, tillage intensity, and $\mathrm{N}$ applications are three management practices that have been shown to affect $\mathrm{N}$-mineralization rates (Campbell et al., 1991; Franzluebbers et al., 1994a).

In 1984, a study was initiated near Mandan, ND to compare the performance of a 3-yr annual cropping system (one crop each year) with a crop-fallow (crop every other year). There were three tillage intensities and three $\mathrm{N}$ rates within each cropping system. This study provided an opportunity to compare the effects of a number of management practices on crop yields and soil properties after several cycles of the contrasting cropping systems (Black and Tanaka, 1997). The objective of the work reported here was to compare $\mathrm{N}$-mineralization rates after these various management practices had been in place for $10 \mathrm{yr}$.

\section{MATERIALS AND METHODS}

\section{Study Site}

The field site was located in Morton County $10 \mathrm{~km}$ southwest of Mandan, ND. Soils at the site are a Temvik-Wilton silt loam (fine-silty, mixed Typic and Pachic Haploborolls). 
Table 1. Analysis of variance (ANOVA) tables for the three models used to test for treatment effects on $\mathbf{N}$-mineralization rates in the 0- to 0.05-m depth.

\begin{tabular}{|c|c|c|c|c|c|c|c|c|}
\hline \multicolumn{9}{|c|}{ Model $\dagger$} \\
\hline \multicolumn{3}{|c|}{ Within SW-F system } & \multicolumn{3}{|c|}{ Between SW-F and SW-WW-SF systems } & \multicolumn{3}{|c|}{ Within SW-WW-SF system } \\
\hline Source & d.f. & $\boldsymbol{P}<$ & Source & d.f. & $\boldsymbol{P}<$ & Source & d.f. & $\boldsymbol{P}<$ \\
\hline $\begin{array}{l}\text { Stage } \\
E_{\mathrm{A}}=\text { Rep } \times \text { Stage } \\
\mathbf{N} \text { rate } \\
E_{\mathrm{B}}=\mathbf{R e p} \times \mathbf{N} \text { rate } \\
\text { Stage } \times \mathbf{N} \text { rate } \\
E_{\mathbf{C}}=\mathbf{R e p} \times \text { Stage } \times \mathbf{N} \text { rate } \\
\text { Tillage } \\
E_{\mathrm{D}}=\mathbf{R e p} \times \text { Tillage } \\
\text { Stage } \times \text { Tillage } \\
E_{\mathrm{E}}=\mathbf{R e p} \times \text { Stage } \times \text { Tillage } \\
\mathbf{N} \text { rate } \times \text { Tillage } \\
E_{\mathrm{F}}=\mathbf{R e p} \times \mathbf{N} \text { rate } \times \text { Tillage } \\
\text { Stage } \times \mathbf{N} \text { rate } \times \text { Tillage } \\
E_{\mathrm{G}}=\mathbf{R e p} \times \text { Stage } \times \\
\mathbf{N} \text { rate } \times \text { Tillage } \\
\text { Total }\end{array}$ & $\begin{array}{r}1 \\
2 \\
2 \\
4 \\
2 \\
4 \\
2 \\
4 \\
2 \\
4 \\
4 \\
8 \\
4 \\
\\
\mathbf{8} \\
\mathbf{5 3}\end{array}$ & $\begin{array}{l}0.44 \\
0.44 \\
0.11 \\
0.31 \\
0.11 \\
0.58 \\
0.03\end{array}$ & $\begin{array}{l}\text { System } \\
E_{\mathrm{A}}=\mathbf{R e p} \times \text { System } \\
\mathbf{N} \text { rate } \\
E_{\mathrm{B}}=\mathbf{R e p} \times \mathbf{N} \text { rate } \\
\text { System } \times \mathbf{N} \text { rate } \\
E_{\mathrm{C}}=\mathbf{R e p} \times \text { System } \times \mathbf{N} \text { rate } \\
\text { Tillage } \\
E_{\mathrm{D}}=\mathbf{R e p} \times \text { Tillage } \\
\text { System } \times \text { Tillage } \\
E_{\mathrm{E}}=\mathbf{R e p} \times \text { System } \times \text { Tillage } \\
\mathbf{N} \text { rate } \times \text { Tillage } \\
E_{\mathrm{F}}=\mathbf{R e p} \times \mathbf{N} \text { rate } \times \text { Tillage } \\
\text { System } \times \mathbf{N} \text { rate } \times \text { Tillage } \\
E_{\mathrm{G}}=\mathbf{R e p} \times \text { System } \times \\
\mathbf{N} \text { rate } \times \text { Tillage } \\
\text { Total }\end{array}$ & $\begin{array}{l}1 \\
2 \\
2 \\
4 \\
2 \\
4 \\
2 \\
4 \\
2 \\
4 \\
4 \\
8 \\
4\end{array}$ & $\begin{array}{l}0.06 \\
0.31 \\
0.47 \\
0.001 \\
0.002 \\
0.02 \\
0.07\end{array}$ & $\begin{array}{l}\text { Crop } \\
E_{\mathrm{A}}=\text { Rep } \times \text { System } \\
\mathbf{N} \text { rate } \\
E_{\mathrm{B}}=\mathbf{R e p} \times \mathbf{N} \text { rate } \\
\text { Crop } \times \mathbf{N} \text { rate } \\
E_{\mathrm{C}}=\mathbf{R e p} \times \text { crop } \times \mathbf{N} \text { rate } \\
\text { Tillage } \\
E_{\mathrm{D}}=\mathbf{R e p} \times \text { Tillage } \\
\text { Crop } \times \text { Tillage } \\
E_{\mathrm{E}}=\mathbf{R e p} \times \mathbf{C r o p} \times \text { Tillage } \\
\mathbf{N} \text { rate } \times \text { Tillage } \\
E_{\mathrm{F}}=\mathbf{R e p} \times \mathbf{N} \text { rate } \times \text { Tillage } \\
\text { Crop } \times \mathbf{N} \text { rate } \times \text { Tillage } \\
E_{\mathrm{G}}=\mathbf{R e p} \times \mathbf{C r o p} \times \\
\quad \mathbf{N} \text { rate } \times \text { Tillage } \\
\text { Total }\end{array}$ & $\begin{array}{l}2 \\
4 \\
2 \\
4 \\
4 \\
8 \\
2 \\
4 \\
4 \\
8 \\
4 \\
8 \\
8\end{array}$ & 0.02 \\
\hline
\end{tabular}

† SW-F is spring wheat-fallow system; SW-WW-SF is spring wheat-winter wheat-sunflower system.

Annual precipitation is highly variable and averages $410 \mathrm{~mm}$ with $60 \%$ received during the growing season. Average annual temperature is $4^{\circ} \mathrm{C}$ and daily averages range from a maximum of $21^{\circ} \mathrm{C}$ during the summer to a minimum of $-11^{\circ} \mathrm{C}$ during the winter.

Two cropping systems were chosen for comparison: spring wheat-fallow (SW-F) and an annual rotation of spring wheat, winter wheat, and sunflower (SW-WW-SF). In this region, spring wheat is typically planted in April and harvested in August, winter wheat is planted in September and harvested the following July, and sunflowers are planted in May and harvested in October. All phases of each rotation were present each year, resulting in five fields per replication. The study was replicated three times. Within each cropping system there were three tillage treatments (conventional tillage, minimum tillage, and no-tillage), and three $\mathrm{N}$ rates $(0,22$, and $45 \mathrm{~kg}$ $\mathrm{ha}^{-1}$ applied during the crop year in the SW-F system and 34,67 , and $101 \mathrm{~kg} \mathrm{ha}^{-1}$ each year in the SW-WW-SF system). The reduced $\mathrm{N}$ rates in the crop-fallow system are necessary to compensate for inorganic $\mathbf{N}$ that accumulates during the fallow period. Tillage treatments were randomized and applied as three strips across each field and the $\mathrm{N}$ rates were randomized and applied as three strips perpendicular to the tillage strips. This resulted in nine subfields ( 46 by $24 \mathrm{~m}$ ) within each field. These subfields were of sufficient size to allow use of field scale equipment for all operations. Conventional tillage utilized an undercutter (sweep plow), a chisel plow, and a double disk in the fall and spring to control weeds and incorporate crop residue. Minimum tillage consisted of one or two tillages with an undercutter in the spring and herbicides to control weeds. No-tillage relied solely on herbicides for weed control. Surface residue at planting covered $<30 \%$ of the soil under conventional tillage, between 30 and $60 \%$ under minimum tillage, and $>60 \%$ under no-tillage.

In the spring of 1995, prior to field operations, soil samples were collected from the 0 - to $0.05-\mathrm{m}$ and 0.05 - to $0.15-\mathrm{m}$ depths of all $\mathrm{N}$ rate by tillage treatment subfields in all fields. The 270 samples were stored at $-5^{\circ} \mathrm{C}$ until the laboratory mineralization study was initiated.

\section{Laboratory Methods}

The laboratory incubation method was based on the procedure described by Stanford and Smith (1972). Soil (15 g) was added to an equal amount of silica sand and thoroughly mixed. The mixture was transferred to a glass leaching tube and glass wool was placed on the soil surface to prevent dispersion of the sample during leaching. The substrate was compacted slightly and leached with $100 \mathrm{~mL}$ of $0.01 \mathrm{M} \mathrm{CaCl}_{2}$ under a suction of $0.7 \mathrm{MPa}$ to remove mineral N. Leachate was brought to $100 \mathrm{~mL}$ with $0.01 \mathrm{M} \mathrm{CaCl}_{2}$. The leaching tube was covered with Parafilm ${ }^{1}$ (American National Can, Greenwich, CT). A hole was made in the Parafilm to ensure aeration. Leaching tubes were weighed and stored upright in an incubator at $35^{\circ} \mathrm{C}$. Tubes were reweighed weekly and weight adjusted with distilled water. Every 2 wk tubes were leached with $100 \mathrm{~mL}$ of $0.01 \mathrm{M} \mathrm{CaCl}_{2}$ and returned to the incubator. Tubes were incubated for a total of $8 \mathrm{wk}$. Leachates were stored at $-5^{\circ} \mathrm{C}$ until they could be analyzed for inorganic $\mathrm{N}$ content.

Inorganic $\mathrm{N}$ content of leachate was determined by quickly thawing the samples and determining $\mathrm{NH}_{4}$ and $\mathrm{NO}_{2}$ plus $\mathrm{NO}_{3}$ content by automated colorimetric analysis using a Lachat flow through ion analyzer (Zellweger Analytics, Inc., Milwaukee, WI).

\section{Statistical Analysis}

The $\mathrm{N}$-mineralization rates were calculated by regressing cumulative inorganic $\mathrm{N}$ release on time. Nitrogen-mineralization rates and bulk density values were used to calculate $\mathrm{N}$-mineralization on an aerial basis $\left(\mathrm{kg} \mathrm{N} \mathrm{ha}^{-1} \mathrm{wk}^{-1}\right)$ and the statistical analyses were performed using these values.

The experimental design of the field study was a strip-strip random blocks design with $\mathrm{N}$ rate as strips going one direction, tillage treatment as perpendicular strips, and the crop system being the whole-plot treatment. There were three valid models for testing the effect of $\mathrm{N}$ rate and tillage on $\mathrm{N}$-mineralization rates. The first model compared the effect of $\mathrm{N}$ rate and tillage on N-mineralization rates within the SW-F system (Table 1). The $\mathrm{N}$-mineralization rates of soils having a crop the previous year were compared with those of soils that were fallowed the previous year (stage effect). The second model compared the effect of $\mathrm{N}$ rate and tillage on $\mathrm{N}$-mineralization rates between the SW-F system and the SW-WW-SF system (Table 1). The $\mathrm{N}$-mineralization rates from soils growing spring wheat the previous year in the SW-F system were compared with those of soils growing spring wheat the previous year in the SW-WW-SF system (system effect). This model compared $\mathrm{N}$-mineralization rates in soils cropped every other year with those of soils cropped annually (Table 1). The third model

\footnotetext{
${ }^{1}$ Trade names are included for the benefit of the reader and imply no endorsement or preferential treatment of the product by the USDA.
} 
compared the effect of $\mathrm{N}$ rate and tillage on $\mathrm{N}$-mineralization rates within the SW-WW-SF system (Table 1). Nitrogen-mineralization rates of soils growing either spring wheat, winter wheat, or sunflowers the previous year in the annual cropping system were compared (crop effect). The three models were analyzed using analysis of variance (ANOVA). Least significant differences $\left(\mathrm{LSD}_{0.05}\right)$ were calculated and used to separate means. Results are reported as means \pm standard error of the mean.

\section{RESULTS AND DISCUSSION}

Very little $\mathrm{NH}_{4}$ was present in the leachates. Therefore, $\mathrm{NH}_{4}$ was combined with $\mathrm{NO}_{2}$ and $\mathrm{NO}_{3}$ to give total $\mathrm{N}$ mineralized. Release of inorganic $\mathrm{N}$ was found to be linear with time. Mineralization rates were calculated using linear regression and ranged from 2.3 to $22.9 \mu \mathrm{g}$ $\mathrm{g}^{-1} \mathrm{wk}^{-1}$ with coefficients of determination ranging from 0.86 to 0.99 . While $\mathrm{N}$ mineralization is more commonly found to be linearly related to the square root of time and to fit a first order model (Stanford and Smith, 1972), others have reported a linear relationship between $\mathrm{N}$ mineralization and time. Tabatabai and Al-Khafaji (1980) measured $\mathbf{N}$ mineralization in 12 common Iowa soils and found that $\mathrm{N}$ release was linearly related to time with rates ranging from 7.7 to $17.0 \mu \mathrm{g} \mathrm{g}^{-1} \mathrm{wk}^{-1}$. Subzero storage of field moist soil has been shown to have little effect on $\mathrm{N}$ mineralization (Addiscott, 1983) and $\mathbf{N}$ release is often linearly related to time under these conditions. Air drying and rewetting has been shown to stimulate $\mathrm{N}$ mineralization early in the incubation period resulting in a curvilinear response (Beauchamp et al., 1986; Cabrera, 1993).

\section{Nitrogen-Mineralization Rates in the Spring Wheat-Fallow System}

Treatment effects were limited to the 0 - to $0.05-\mathrm{m}$ depth. The $\mathrm{N}$-mineralization rates were similar $(2.3 \pm$ $0.4 \mathrm{~kg} \mathrm{ha}^{-1} \mathrm{wk}^{-1}$ ) among soils from the 0.05 - to $0.15-\mathrm{m}$ depth that had been cropped the previous year and those that had been fallowed the previous year. Tillage and $\mathrm{N}$-rate treatments did not affect $\mathrm{N}$-mineralization rates in the 0.05 - to $0.15-\mathrm{m}$ depth.

The patterns exhibited by $\mathbf{N}$ mineralization in the surface soils resulted in a significant stage $x$ tillage $\times$ $\mathrm{N}$ rate interaction (Table 1 ). The $\mathrm{N}$-mineralization rates were higher in soils fallowed the previous year at the low and high $\mathrm{N}$ rates under conventional tillage (Table 2 ). At the medium $\mathrm{N}$ rate under conventional tillage and all $\mathrm{N}$ rates under minimum and no-tillage, $\mathrm{N}$-mineralization rates were similar (Table 2).

The $\mathrm{N}$-mineralization rates were higher in conven- tionally tilled surface soils that had been fallowed the previous year than in soils that were cropped the previous year (Table 2), a pattern similar to that reported by others (Campbell et al., 1989). As tillage became less intense, $\mathrm{N}$-mineralization rates became more similar between soils that had been cropped and those that had been fallowed the previous year. Our results are similar to those of Franzluebbers and Arshad (1996) who compared $\mathrm{N}$-mineralization rates in soils following barley (Hordeum vulgare L.) with those of soils fallowed the previous year in Alberta, Canada. They reported $\mathrm{N}$-mineralization rates that were similar among tillage treatments in soils that had been cropped to barley the previous year; higher $\mathrm{N}$-mineralization rates in soils that had been fallowed the previous year than in soils cropped to barley the previous year; and higher N-mineralization rates in conventionally tilled fallowed soils than in minimum and no-tilled fallow soils.

\section{Nitrogen-Mineralization Rates between the Spring Wheat-Fallow and the Spring Wheat-Winter Wheat-Sunflower Systems}

The patterns exhibited by $\mathrm{N}$ mineralization in the surface soils resulted in a significant system $\times$ tillage $\times$ $\mathrm{N}$ rate interaction (Table 1). The $\mathrm{N}$-mineralization rates were higher in soils supporting spring wheat the previous year in the SW-WW-SF system than in soils supporting spring wheat the previous year in the SW-F system at the high $\mathrm{N}$ rate under conventional tillage and under the two lower $\mathrm{N}$ rates under minimum and notillage (Table 3 ). These results are consistent with previous reports of higher $\mathrm{N}$-mineralization rates in soils from annual cropping systems than in soils from crop-fallow systems (Dormaar, 1983; Biederbeck et al., 1984; Janzen, 1987; Campbell et al., 1989).

In the 0.05 - to $0.15-\mathrm{m}$ depth, $\mathrm{N}$-mineralization rates were lower in the SW-F system $\left(2.4 \pm 0.2 \mathrm{~kg} \mathrm{ha}^{-1} \mathrm{wk}^{-1}\right)$ than in the SW-WW-SF system $\left(3.6 \pm 0.1 \mathrm{~kg} \mathrm{ha}^{-1} \mathrm{wk}^{-1}\right)$. Nitrogen rate and tillage treatments did not affect $\mathrm{N}$-mineralization rates within each of the cropping systems.

In crop-fallow systems, crop residues are added to the soil every other year. Spring wheat residue has a high $\mathrm{C} / \mathrm{N}$ ratio and as this residue decomposes $\mathrm{N}$ is immobilized in the microbial biomass. As decomposition proceeds and humification of the residue occurs, $\mathrm{N}$ is mineralized and, as noted earlier, $\mathrm{N}$-mineralization rates increase during the fallow year. In annual cropping systems, crop residues are added to the soil every year. When the annual cropping system utilizes several crops in a rotation, residues of varying quality are added to

Table 2. Nitrogen-mineralization rates (mean \pm SE) for soil from the 0 - to $0.05-m$ layer in plots supporting spring wheat the previous year with that fallowed the previous year as a function of tillage and $\mathbf{N}$ rate.

\begin{tabular}{|c|c|c|c|c|c|c|c|c|c|}
\hline \multirow[b]{3}{*}{ Stage } & \multicolumn{9}{|c|}{ Tillage } \\
\hline & \multicolumn{3}{|c|}{ Conventional } & \multicolumn{3}{|c|}{ Minimum } & \multicolumn{3}{|c|}{ No-till } \\
\hline & $0 \dagger$ & 22 & 45 & $\mathbf{0}$ & 22 & 45 & $\mathbf{0}$ & 22 & 45 \\
\hline $\begin{array}{l}\text { Spring wheat } \\
\text { Fallow } \text { LSD }_{0.05}=\end{array}$ & $\begin{array}{c}5.0 \pm 1.1 \\
8.5 \pm 1.3 \\
1.5\end{array}$ & $\begin{array}{c}5.6 \pm 1.6 \\
6.3 \pm 0.6 \\
\text { NS }\end{array}$ & $\begin{array}{c}4.4 \pm 1.4 \\
9.9 \pm 1.5 \\
1.5\end{array}$ & $\begin{array}{c}5.5 \pm 1.4 \\
7.6 \pm 1.6 \\
\text { NS }\end{array}$ & $\begin{array}{c}\mathrm{kg} \mathrm{ha}^{-1} \mathrm{wk}^{-} \\
6.9 \pm 1.2 \\
6.8 \pm 1.1 \\
\mathrm{NS}\end{array}$ & $\begin{array}{c}6.1 \pm 1.2 \\
5.5 \pm 0.6 \\
\text { NS }\end{array}$ & $\begin{array}{c}6.6 \pm 1.0 \\
6.9 \pm 0.3 \\
N S\end{array}$ & $\begin{array}{c}4.8 \pm 0.8 \\
5.6 \pm 0.3 \\
\text { NS }\end{array}$ & $\begin{array}{c}5.6 \pm 1.3 \\
6.1 \pm 0.8 \\
\text { NS }\end{array}$ \\
\hline
\end{tabular}

$\dagger \mathbf{N}$ rates (kilograms per hectare). 
Table 3. Nitrogen-mineralization rates (mean $\pm \mathrm{SE}$ ) for soil from the 0 - to $0.05-\mathrm{m}$ depth in plots supporting spring wheat the previous year in a crop-fallow system with that in an annual cropping system as a function of tillage and $\mathrm{N}$ rate.

\begin{tabular}{|c|c|c|c|c|c|c|c|c|c|}
\hline \multirow[b]{3}{*}{ System $\dagger$} & \multicolumn{9}{|c|}{ Tillage } \\
\hline & \multicolumn{3}{|c|}{ Conventional } & \multicolumn{3}{|c|}{ Minimum } & \multicolumn{3}{|c|}{ No-tillage } \\
\hline & $0 / 34 \ddagger$ & $22 / 67$ & 45/101 & $0 / 34$ & $22 / 67$ & 45/101 & $0 / 34$ & $22 / 67$ & 45/101 \\
\hline & & & & & $\mathbf{k g ~ h a}^{-1} \mathbf{w k}$ & & & & \\
\hline $\begin{array}{l}\text { SW-F } \\
\text { SW-WW-SF } \\
\text { LSD }_{0.05}=\end{array}$ & $\begin{array}{c}5.0 \pm 1.1 \\
7.8 \pm 1.2 \\
\text { NS }\end{array}$ & $\begin{array}{c}5.6 \pm 1.6 \\
7.6 \pm 1.3 \\
\text { NS }\end{array}$ & $\begin{array}{c}4.4 \pm 1.4 \\
7.4 \pm 0.5 \\
3.00\end{array}$ & $\begin{array}{c}5.5 \pm 1.4 \\
8.7 \pm 0.8 \\
\mathbf{3 . 0 0}\end{array}$ & $\begin{array}{c}6.9 \pm 1.2 \\
10.2 \pm 1.8 \\
3.00\end{array}$ & $\begin{array}{c}6.6 \pm 1.2 \\
8.3 \pm 0.7 \\
\mathrm{NS}\end{array}$ & $\begin{aligned} 6.6 & \pm 1.0 \\
18.5 & \pm 2.9 \\
3.00 & \end{aligned}$ & $\begin{aligned} 4.8 & \pm 0.8 \\
13.2 & \pm 3.3 \\
3.00 & \end{aligned}$ & $\begin{array}{c}5.6 \pm 1.3 \\
7.7 \pm 0.2 \\
\text { NS }\end{array}$ \\
\hline
\end{tabular}

$\dagger \mathrm{SW}-\mathrm{F}$ is spring wheat-fallow; SW-WW-SF is spring wheat-winter wheat-sunflower.

$\$ N$ rate for the $S W-F$ system/N rate for the SW-WW-SF system (kilograms per hectare).

the soil. With time, the annual cropping system has larger residue inputs, with residues in various stages of decomposition present at any given time. With time, reducing the incidence of fallow should result in an increase in soil organic $\mathrm{C}$ and $\mathrm{N}$, as well as the labile or active organic fraction and soil microbial diversity and activity (Biederbeck et al., 1994; Franzluebbers et al., 1994a).

\section{Nitrogen-Mineralization Rates within the Spring Wheat-Winter Wheat-Sunflower System}

In the 0 - to $0.05-\mathrm{m}$ soil layer $\mathrm{N}$-mineralization rates were lower in fields that supported winter wheat the previous year $\left(6.8 \pm 0.5 \mathrm{~kg} \mathrm{ha}^{-1} \mathrm{wk}^{-1}\right)$ than in fields that supported either spring wheat $\left(9.9 \pm 0.8 \mathrm{~kg} \mathrm{ha}^{-1}\right.$ $\mathrm{wk}^{-1}$ ) or sunflower $\left(9.2 \pm 0.6 \mathrm{~kg} \mathrm{ha}^{-1} \mathrm{wk}^{-1}\right)$ the previous year (significant crop effect, Table 1). In the 0 - to 0.05-m depth, $\mathrm{N}$-mineralization rates were higher under no-tillage than under minimum or conventional tillage at the two lower $\mathbf{N}$ rates and higher under minimum and no-tillage than under conventional tillage at the high $N$ rate (Table 4) resulting in a significant tillage $X$ $\mathrm{N}$ rate interaction (Table 1 ). In the 0.05 - to 0.15 -m soil layer, $\mathrm{N}$-mineralization rates were similar across treatments $\left(3.3 \pm 1.0 \mathrm{~kg} \mathrm{ha}^{-1} \mathrm{wk}^{-1}\right)$.

The lower $\mathrm{N}$-mineralization rates associated with soil from fields supporting winter wheat the previous year compared with soils supporting either spring wheat or sunflower the previous year contrasts with the work of Franzluebbers et al. (1994a,b, 1995), who reported that crop sequence did not greatly affect $\mathrm{N}$-mineralization rates in soils of the Southern Great Plains. This contrast may be due to the intensity of the rotations. In the Northern Great Plains, three crops are grown during $3 \mathrm{yr}$, while in the Southern Great Plains only 2 yr were needed to grow three crops. In the Northern Great Plains, winter wheat is harvested in mid summer and sunflowers are planted in late spring. Hence, in the

Table 4. Nitrogen-mineralization rates (mean \pm SE) for soil from the 0 - to $0.05-\mathrm{m}$ depth as a function of tillage and $\mathrm{N}$ rate in the annual cropping system.

\begin{tabular}{lrrr}
\hline & \multicolumn{3}{c}{ N rate } \\
\cline { 2 - 4 } Tillage & \multicolumn{1}{c}{$34 \dagger$} & \multicolumn{1}{c}{67} & \multicolumn{1}{c}{101} \\
\hline & & $\mathrm{kg} \mathrm{ha}^{-1} \mathbf{w k}^{-1}$ & \\
\cline { 2 - 4 } Conventional & $\mathbf{7 . 9} \pm 0.8 \mathrm{a} \dagger$ & $7.7 \pm 0.8 \mathrm{a}$ & $\mathbf{5 . 5} \pm \mathbf{0 . 8 a}$ \\
Minimum & $\mathbf{8 . 6} \pm \mathbf{0 . 6 a}$ & $\mathbf{7 . 8} \pm \mathbf{1 . 0 \mathrm { a }}$ & $\mathbf{7 . 3} \pm \mathbf{0 . 6 b}$ \\
No-tillage & $\mathbf{1 4 . 1} \pm \mathbf{1 . 8 b}$ & $\mathbf{1 1 . 0} \pm \mathbf{1 . 2 b}$ & $\mathbf{7 . 9} \pm \mathbf{0 . 5 b}$ \\
\hline
\end{tabular}

$\dagger$ Kilograms per hectare.

$\$$ LSD $_{0.05}=1.6$; value in a column followed by different letters are significantly different. rotation used in this study, there was a longer period of time between residue addition following harvest and planting of the subsequent crop following winter wheat than following spring wheat or sunflower. Decomposition of the winter wheat residue having a high $\mathrm{C} / \mathrm{N}$ ratio would have resulted in $\mathrm{N}$ immobilization. Very little decomposition of the spring wheat or sunflower residue would have occurred prior to the soil freezing. When the soils were collected, soil microbial activity would have just begun and $\mathrm{N}$-mineralization of partially humified residue would have been observed, with $\mathrm{N}$ immobilization associated with previous crop residue decomposition occurring later in the spring.

\section{Tillage Effects on Nitrogen Mineralization}

Nitrogen mineralization generally increased in the 0 to $0.05-\mathrm{m}$ layer as intensity of tillage decreased in most comparisons (Tables 3 and 4). Tillage incorporates crop residue into the soil, making it more available to soil microorganisms. Incorporating residue exposes more soil to the sun, which lowers the soil albedo, resulting in higher soil temperatures. Tillage also aerates and dries the soil. As tillage intensity decreases, crop residue is made available to soil microorganisms at a slower rate for a longer duration, soil temperatures are lower, the soil is more moist, and the soil is in a less oxidative condition (Doran, 1980). With time, conditions under no-tillage result in an increase in microbial numbers and activity near the soil surface and no change or a decline in microbial numbers and activity at lower depths (Doran, 1980; Carter and Rennie, 1982; Franzluebbers et al., 1994a). When producers switch from conventional tillage to no-tillage, a common observation is that $\mathrm{N}$-fertilization rates need to be increased to achieve expected yields; however, after no-tillage practices have been utilized for a few growing seasons, the $\mathrm{N}$-suppling potential of the soil increases (Franzluebbers et al., 1994a,b).

\section{Nitrogen-Fertilization Rate Effects on Nitrogen Mineralization}

The $\mathrm{N}$-rate treatment effect was significant in a number of interactions in all comparisons in the 0 - to $0.05-\mathrm{m}$ depth (Table 1$)$. Others have reported no effect of $\mathrm{N}$-fertilization rate on $\mathrm{N}$-mineralization rates (Franzluebbers et al., 1994a,b). However, Campbell et al. (1991) found that $\mathrm{N}$-mineralization rates were higher in annual cropping systems that were fertilized than in unfertilized annual cropping systems or in fertilized and 
unfertilized crop-fallow systems. Nitrogen is physiologically mobile within a plant (Marschner, 1986), and most $\mathrm{N}$ will be transported to growing points or storage organs within the plant. The storage organs are the part of the plant that is harvested and, hence, little $\mathrm{N}$ is left in plant parts that constitute crop residue. Therefore, the $\mathrm{C} / \mathrm{N}$ ratio of crop residue will probably be similar among $\mathrm{N}$ rates. At higher $\mathbf{N}$ rates, a larger amount of residue will be produced. During decomposition of the high $\mathrm{C} / \mathrm{N}$ ratio residue, $\mathrm{N}$ will be immobilized and, as observed in this study, $\mathrm{N}$-mineralization rates may be lower at high $\mathrm{N}$ rates than at low $\mathrm{N}$ rates.

\section{CONCLUSIONS}

After $10 \mathrm{yr}, \mathrm{N}$-mineralization rates were higher in the annual cropping system than in the crop-fallow system and increased as intensity of tillage decreased. Cultivation of the prairie soils has resulted in a loss of organic matter and fertility (Campbell and Souster, 1982). Increased $\mathrm{N}$-mineralization rates represent an increase in the amount of $\mathrm{N}$ stored in labile organic forms. Soils with a larger labile $\mathrm{N}$ pool are able to supply a greater portion of crop $\mathrm{N}$ during the growing season and require less fertilizer $\mathrm{N}$. In addition, $\mathrm{N}$ stored in labile forms is not susceptible to leaching losses. Results from our study suggest that more intensive cropping combined with conservation tillage and appropriate $\mathbf{N}$ fertilizer management may ameliorate the decline in $\mathrm{N}$ fertility. Changes in $\mathrm{N}$-mineralization rates associated with tillage and $\mathrm{N}$ rates were detected only in the $0-$ to $0.05-\mathrm{m}$ soil depth, while changes associated with more intensive cropping were detected to a depth of $0.15 \mathrm{~m}$, suggesting that eliminating fallow from the system is the most important management decision affecting long-term soil $\mathrm{N}$ fertility in the Northern Great Plains.

\section{ACKNOWLEDGMENTS}

The authors thank James Harms and Larry Renner for maintaining the field sites; Mary Kay Tokach, Gary Brucker, Ivana Witt, and Jennifer Mees for field and laboratory assistance; Gary Richardson for statistical assistance; and the ND Area IV Soil Conservation Districts for leasing the study site.

\section{REFERENCES}

Addiscott, T.M. 1983. Kinetics and temperature relationships of mineralization and nitrification in Rothamstad soils with different histories. J. Soil Sci. 34:343-353.

Beauchamp, E.G., W.D. Reynolds, D. Brasche-Villeneuve, and K. Kirby. 1986. Nitrogen mineralization kinetics with different soil pretreatments and cropping histories. Soil Sci. Soc. Am. J. 50: $1478-1483$

Biederbeck, V.O., C.A. Campbell, and R.P. Zentner. 1984. Effect of crop rotation and fertilization on some biological properties of a loam in southwestern Saskatchewan. Can. J. Soil Sci. 64:355-367.

Biederbeck, V.O., H.H. Janzen, C.A. Campbell, and R.P. Zentner.
1994. Labile soil organic matter as influenced by cropping practices in an arid environment. Soil Biol. Biochem. 26:1647-1656.

Black, A.L., P.L. Brown, A.D. Halvorson, and F.H. Siddoway. 1981 Dryland cropping strategies for efficient water-use to control saline seeps in the Northern Great Plains, USA. Agric. Water Manage. 4:295-311.

Black, A.L., and D.L. Tanaka. 1997. A conservation tillage-cropping system study in the Northern Great Plains of the United States. p. 335-341. In E.A. Paul et al. (ed.) Soil organic matter in agroecosystems: Long-term experiments in North America. CRC Press, Boca Raton, FL.

Cabrera, M.L. 1993. Modeling the flush of nitrogen mineralization caused by drying and rewetting soils. Soil Sci. Soc. Am. J. 57:63-66.

Campbell, C.A., V.O. Biederbeck, M. Schnitzer, F. Selles, and R.P. Zentner. 1989. Effect of 6 years of zero tillage and $N$ fertilizer management on changes in soil quality of an orthic brown chernozem in southwestern Saskatchewan. Soil Tillage Res. 14:39-52.

Campbell, C.A., G.P. LaFond, A.J. Leyshon, R.P. Zentner, and H.H. Janzen. 1991. Effect of cropping practices on the initial potential rate of $\mathbf{N}$ mineralization in a thin chernozem. Can. J. Soil Sci. 71:43-53.

Campbell, C.A., and W. Souster. 1982. Loss of organic matter and potentially mineralizable nitrogen from Saskatchewan soils due to cropping. Can. J. Soil Sci. 62:651-656.

Carter, M.R., and D.A. Rennie. 1982. Changes in soil quality under zero tillage farming systems: Distribution of microbial biomass and mineralizable C and N potentials. Can. J. Soil Sci. 62:587-597.

Doran, J.W. 1980. Soil microbial and biochemical changes associated with reduced tillage. Soil Sci. Soc. Am. J. 44:765-771.

Dormaar, J.F. 1983. Chemical properties of soil and water-stable aggregates after sixty-seven years of cropping to spring wheat. Plant Soil 75:51-61

Dhuyvetter, K.C., C.R. Thompson, C.A. Norwood, and A.D. Halvorson. 1996. Economics of dryland cropping systems in the Great Plains. J. Prod. Agric. 9:216-222.

Franzluebbers, A.J., and M.A. Arshad. 1996. Soil organic matter pools during early adoption of conservation tillage in northwestern Canada. Soil Sci. Soc. Am. J. 60:1422-1427.

Franzluebbers, A.J., F.M. Hons, and D.A. Zuberer. 1994a. Long-term changes in soil carbon and nitrogen pools in wheat management systems. Soil Sci. Soc. Am. J. 58:1639-1645.

Franzluebbers, A.J., F.M. Hons, and D.A. Zuberer. 1994b. Seasonal changes in soil microbial biomass and mineralizable $\mathrm{C}$ and $\mathrm{N}$ in wheat management systems. Soil Biol. Biochem. 26:1469-1475.

Franzluebbers, A.J., F.M. Hons, and D.A. Zuberer. 1995. Tillage and crop effect on seasonal soil carbon and nitrogen dynamics. Soil Sci. Soc. Am. J. 59:1618-1624.

Fox, R.H., and V.A. Bandel. 1986. Nitrogen utilization with no-tillage. p. 117-148. In M.A. Sprague and G.B. Triplett (ed.) No-tillage and surface-tillage agriculture. The tillage revolution. John Wiley \& Sons, New York

Holtzer, T.O., R.L. Anderson, M.P. McMullen, and F.B. Peairs. 1996 Integrated pest management of insects, plant pathogens, and weeds in dryland cropping systems of the Great Plains. J. Prod. Agric. 9:200-208.

Janzen, H.H. 1987. Soil organic matter characteristics after long-term cropping to various spring wheat rotations. Can. J. Soil Sci. 67 845-856.

Marschner, H. 1986. Mineral nutrition in higher plants. Academic Press, Orlando, FL.

Norwood, C. 1994. Profile water distribution and grain yield as affected by cropping system and tillage. Agron. J. 86:558-563.

Norwood, C.A., and K.C. Dhuyvetter. 1993. An economic comparison of the wheat-fallow and wheat-sorghum-fallow cropping systems J. Prod. Agric. 6:261-266.

Stanford, G., and S.J. Smith. 1972. Nitrogen mineralization potential of soils. Soil Sci. Soc. Am. Proc. 36:465-472.

Tabatabai, M.A., and A.A. Al-Khafaji. 1980. Comparison of nitrogen and sulfur mineralization in soils. Soil Sci. Soc. Am. J. 44:1000-1006. 